\title{
Collaborative Cassava-Chip Supply Chain Mobile Application in Thailand
}

\author{
https://doi.org/10.3991/ijim.v14i01.11180
}

\author{
Thanika Chintanapunt, Rath Pichyangkura $(\bowtie)$ \\ Chulalongkorn University, Bangkok, Thailand \\ prath@chula.ac.th
}

\begin{abstract}
Cassava-chip is considered one of Thailand's most important economic crops and Thailand is the world's largest cassava products exporter. Thai government is prioritizing the cassava production in their "Mega farm" strategy in support of agricultural economic and collaboration between farmer, public and private sectors. The collaborative model is an integrated supply chain that manages the multiple stakeholders. Moreover, implementing the collaborative supply chain (CSC) has improve overall performance of the entire supply chain. The study aims to review existing literature on collaborative model and critical success factors in the agriculture supply chain context during 2008-2018 and the 20-year agriculture and cooperatives strategy (2017-2036). The six key collaborative success factors are identified: Business Management, Information Technology, Value Added Process, SC Relationship, Top Management Commitment, Partnership, Service Quality, Process, Resource Capability, Environment Uncertainties, Customer Satisfaction. The hypothesis will be tested by the linear regression analysis and develop the prototype of CSC mobile application to create the collaboration in cassava chip industry. Then, the result will be embedded into mobile application. The application will later be used to provide more appropriate third-party system to enhance the collaborative cassava chip supply chain in Thailand. The result shows that all components are supported by the hypothesis and user acceptance test.
\end{abstract}

Keywords-Cassava-chip collaboration, Collaborative Supply Chain, Agriculture mobile application

\section{$1 \quad$ Introduction}

Agriculture products now become an important role in world economy. Particularly, customer demands such as food and biofuel are produced from crops. Moreover, the supply chain of agricultural products has become a huge issue because the citizen increasingly concerned about the safety of the foods being is consumed. At present, the process of farming, distribution, transportation, and other activities are interested for consumers of agricultural products [1][13][37]. Further, consumer behavior as such involves issues related to public health, which is influenced by existing cases on contaminated products [8]. 
Thailand has well known its reputation as the leading an abundance of natural resources and global supplier of agricultural products. Cassava is considered as the most important economic crops in Thailand. An industrial crop has well-developed industry and market in the country, [22]. Thailand was ranked as the world's largest cassava products exporter with 33 million tons of annual production in 2016 which providing about $67 \%$ of the world market [27]. The cassava processing extends primary products to flour by chips and pellets in Thailand which is further processed into high value-added flour derivatives products. Furthermore, if the increasing demand of a cassava product is not supported by a good post-harvest handling, cassava waste would be a problem. Cassava wastes are possible to produce from harvest wastes. Those wastes might be potentially important resources if handled properly [9][16][23][24].

Increasing the efficiencies in a cassava supply chain is important to increasing productivity and reducing problems. Creating a more efficient supply chain involves productive engagement of the functional units in the supply chain and how the information around these units is managed. One of the ways to improve the efficiency in the cassava supply chain is the use of mobile application technology [10]. Mobile application technology in diverse business situations is growing in many developing countries; it provides different opportunities to transfer information and knowledge among players in the supply chain including the government. The use of mobile phones was initially mainly for urban residence but has found social and economic usefulness for the rural populace to obtain information on weather, market and other related issues [1] [7]. Although mobile applications rapidly proliferate, the complicated of application contents still be concerned [28] and how we can leverage the efficiency of mobile application to best serve users [14].

The paper is structured into six sections. In the second section, a review of the existing background literature on CSC and cassava chip industry in Thailand are presented. In the third section, a methodology is presented. The fourth section will show a result and adapt mobile application. Finally, the last section discussion and conclusion with proposed future research.

\section{$2 \quad$ Literature Review}

One of the reasons why Thailand Government are supporting Cassava Ship because the Country is the world's largest cassava products exporter. Thus, it is essential to develop mobile application technology that is workable for cassava supply chain. Not only will help researchers better understand a Collaborative Cassava-Chip Supply Chain Mobile Application in Thailand (CCSC) setting, but it will also set a framework that will serve as a tool for farmers. In this section, current cassava chip industry in Thailand, the definition of collaborative supply chain and existing CSC frameworks in the literature are reviewed. 


\subsection{Current cassava chip industry in Thailand}

Use Cassava chip factories are small-scale enterprises which belong to farmers or small businessmen and are located in close proximity to the growing area. The chipping factories are installed with simple equipment, consisting mainly of a chopper. Roots are loaded into the hopper of the chopping machine by a tracker; after chopping into small pieces, the chips are sun-dried on a cement floor. The final moisture content of chips should be below $14 \%$ and the sand content should not exceed $3 \%$. Normally it takes $2.00-2.50 \mathrm{~kg}$ of fresh roots (with $25 \%$ starch content) to produce $1 \mathrm{~kg}$ of chips (14\% moisture content). Chips are sold to pelletizing manufacturers who either directly export the chips/pellets or sell to traders. In most cases, the small chip factories sell their products to large factories that in turn sell a consolidated consignment to pellet manufacturers. Some portions of cassava chips are used locally for animal feed, as well as feedstock for producing bioethanol, an environmentally friendly, alternative energy for liquid fuel use as a blend with gasoline, i.e. gasohol in the transportation sector. In addition, the biofuel program being established in some countries, in particular China, has driven a marked increase in the export volume of cassava chips. As the high starch content of cassava chips is of value for biotechnological conversion, the demand for chips for this industry is still very promising [29].

Recently, the demand of cassava chips in Thailand has increased dramatically as a result of the national policy of bioethanol production for fuel uses [22]. To produce ethanol from cassava, the starch is initially converted to fermentable sugars, mainly glucose by enzyme or acid process. The sugars are then fermented to ethanol by yeast. To produce 1 liter of anhydrous ethanol, around $2.5 \mathrm{~kg}$ of dried chips $(65 \% \mathrm{starch}$ content, wb) are required; the conversion ratio, however, varies depending on processing efficiency; the most widely used process is Simultaneous Saccharification and Fermentation [33].

For production, Thailand's average growth rate of cassava planted area, harvested area and production from 2012-2017 reaching to $0.45,0.36$ and $0.95 \%$ respectively [27]. Moreover, in 2017 Thailand has about 322 drying yards (cassava chip producer), and most of Thai manufacturers have high experience, knowledge including hi-tech machineries, and from market side, Thailand exports more than $85 \%$ of cassava chips while the rest is consumed domestically in ethanol, chemical and animal feed industry. Furthermore, according to [6], in 2018, Thailand is the biggest cassava exporter in the world with 53 percent of market share, and it has the highest exporting cassava chip value in the world with proportion of $90.52 \%$. Thai cassava chip is mostly exported to China in $99.35 \%$ also. Therefore, the export of cassava chip plays the important role in Thailand especially to China [33].

\subsection{Definition of Collaborative Supply Chain (CSC)}

CSC refer to two or more independent companies plan to work together in order to execute supply chain operations with improve quality industry or success than when acting in individual. CSC relevant definitions can be identified by many researchers. [18][21] suggest a particular degree of relationship among chain members as a means 
to share risks and rewards that result in higher business performance than would be achieved by the firms individually. [3] reports that logistics alliances offer opportunities to dramatically improve customer service and at the same time lower distribution and storage operating costs. [25] CSC defines as the cooperation among firms to allocate resources and capabilities to reach their customers' needs.

CSC also results in performance improvement in the supply chain [5][35][36]. In demand chain management, the supply chain structure when aligned as per the needs of the customer would result in better performance. Hence there is a need to have tight integration of supplier and customer to make a supply chain successful [36][37]. In addition, firms should build collaborative relationships with their supply chain partners in order to achieve efficiencies, flexibility, and sustainable competitive advantage [15] [26].

\subsection{Review of existing CSC frameworks}

Previous literature reveals that there are various perspectives being used to describe a CSC Framework (Table 1). Some perspectives in one model are overlapped with others.

Table 1. Literature Review on CSC Framework

\begin{tabular}{|c|c|c|}
\hline Component & Description & Literature review \\
\hline Business Management & $\begin{array}{l}\text { Managerial initiatives, Management capability, } \\
\text { Organizational involvement Corporate culture; } \\
\text { Quality leadership, Top management support } \\
\text { managerial understanding, Role of organization, } \\
\text { Organizational commitment, Management } \\
\text { support. }\end{array}$ & {$[3][6][13][19][34]$} \\
\hline Information Technology & $\begin{array}{l}\text { Effective use of ERP and MRP system, Tech- } \\
\text { nology capacity, Quality of IT system, Reliabil- } \\
\text { ity of hardware and software, IT strategy orien- } \\
\text { tation, Application of information technology, } \\
\text { Technological capability, ICT, Strategic use of } \\
\text { IT. }\end{array}$ & $\begin{array}{l}{[2][4][5][11]} \\
{[15][16][17][20][24]} \\
{[32][35][37][38]}\end{array}$ \\
\hline Value Added Process & $\begin{array}{l}\text { Key business process reengineering, Just-in- } \\
\text { Time (JIT) methodology, Comprehensiveness } \\
\text { flexibility, Outsourcing non-core activities } \\
\text { Product recycling, Re-engineering material } \\
\text { flow, Customer complaint management, Materi- } \\
\text { al flow management, Automation of authoriza- } \\
\text { tion workflow, life cycle management, Redesign } \\
\text { of the procurement process. }\end{array}$ & $\begin{array}{l}{[2][5][12][13]} \\
{[17][32][35]}\end{array}$ \\
\hline SC Relationship & $\begin{array}{l}\text { Supply chain integration, Collaboration with } \\
\text { partners, Supplier relation, Supplier manage- } \\
\text { ment, Partnership with suppliers, Embracement } \\
\text { of supplier, Business IT partnership, Customer- } \\
\text { supplier relationship, Service relationship } \\
\text { elements, Channel relationship, Inter-firm } \\
\text { collaboration, Interdependent cooperation } \\
\text { Standardizing and integration, Supply chain } \\
\text { partnership selection, }\end{array}$ & $\begin{array}{l}{[2][11][12][13][15]} \\
{[16][20][23][30][31]}\end{array}$ \\
\hline Environment Uncertainties & Policies, Competitive nature, Clear goals, & {$[13][16][23]$} \\
\hline
\end{tabular}




\begin{tabular}{|c|c|c|}
\hline Component & Description & Literature review \\
\hline & $\begin{array}{l}\text { Customer focus, Market competence, Compati- } \\
\text { ble goals, Government policy; Pressure from } \\
\text { competitors, Perceived usefulness, Regulation, } \\
\text { Support activation. }\end{array}$ & \\
\hline Customer Satisfaction & $\begin{array}{l}\text { Customer support, On-time delivery; Data } \\
\text { quality, Superior product quality; Quality im- } \\
\text { provement, System quality; Quality manage- } \\
\text { ment capability, Information quality; Service } \\
\text { quality, Primary customer loyalty, Work per- } \\
\text { formance quality, Service quality. }\end{array}$ & {$[2][5][7][13]$} \\
\hline
\end{tabular}

\section{$2.4 \quad$ Proposed CCSC}

From the literature review was provided in the previous section, those prior six components should be performed to be collaborative framework for cassava chip supply chain in Thailand. The collaborative components are business management, information technology, value added process, SC relationship, environment uncertainties, customer satisfaction. Therefore, this research was conducted by using a quantitative survey to verify on whether these components are contributing to the collaborative model which will influence the successful performance of chip supply chain in Thailand. Six hypotheses are developed for verifications. The research framework is presented in Figure 1, the details are described in Table 2 followed by Hypothesis.

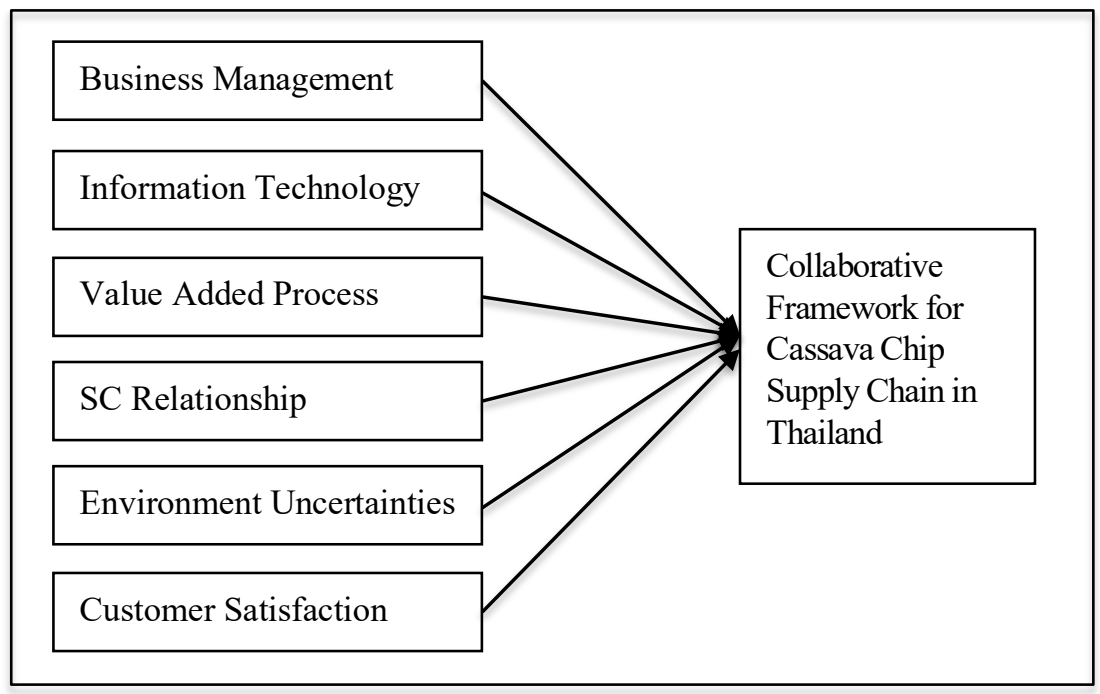

Fig. 1. CCSC Framework

The details in each component such as Business Management, Information Technology, Value Added Process, SC Relationship, Environment Uncertainties, Customer Satisfaction will be shown in table below; 
Table 2. CCSC Framework description in Thailand

\begin{tabular}{|l|l|}
\hline \multicolumn{1}{|c|}{ Components } & \multicolumn{1}{c|}{ Description } \\
\hline Business Management & $\begin{array}{l}\text { Top management commitments are vital as the push organizational reach } \\
\text { goals, and to incite the employees, they must force employee to motivate with } \\
\text { the organization's business objectives. }\end{array}$ \\
\hline Information Technology & $\begin{array}{l}\text { Information system will improve efficiency and effectiveness, ensuring accu- } \\
\text { rate information, and improving communication }\end{array}$ \\
\hline Value Added Process & $\begin{array}{l}\text { Value added process are to improve their company and result business perfor- } \\
\text { mance states that process improvement need identify an objectives, policies } \\
\text { and assignation for the plan's implementation. }\end{array}$ \\
\hline SC Relationship & $\begin{array}{l}\text { SC Relationship such as trust and partnership will indefinitely ease supply } \\
\text { chain adoption among firms and stakeholders. }\end{array}$ \\
\hline Environment Uncertainties & $\begin{array}{l}\text { Governmental factor can be defined as critical success factor. Which all stake- } \\
\text { holder will pay more attention on government-related activities such as regula- } \\
\text { tions, policies, or certification. }\end{array}$ \\
\hline Customer Satisfaction & $\begin{array}{l}\text { To efficient-scale facilities by cost minimization, cost reductions in payment, } \\
\text { and cost saving then, company will give more satisfaction and profit. }\end{array}$ \\
\hline
\end{tabular}

Therefore, all components of CCSC can be identified as 6 hypothesizes;

Hypothesis 1: Business Management influence cassava chip supply chain in Thailand competency which will encourage a successful CCSC.

Hypothesis 2: Information Technology influence cassava chip supply chain in Thailand competency which will encourage a successful CCSC.

Hypothesis 3: Value Added Process influence cassava chip supply chain in Thailand competency which will encourage a successful CCSC.

Hypothesis 4: SC Relationship influence cassava chip supply chain in Thailand competency which will encourage a successful CCSC.

Hypothesis 5: Environment Uncertainties influence cassava chip supply chain in Thailand competency which will encourage a successful CCSC.

Hypothesis 6: Customer Satisfaction influence cassava chip supply chain in Thailand competency which will encourage a successful CCSC.

\section{$3 \quad$ Methodology}

In order to come up with a proposed CCSS framework and hypothesis verification process, this research comprise of the three stages outlined below (sections 3.1 to 3.3).

\subsection{Literature review}

Review the existing CSC with adopted for conducting CCSC Framework with six components; business management, information technology, value added process, SC relationship, environment uncertainties, customer satisfaction that focus on the Cassava-Chip Supply Chain. 


\subsection{Survey questionnaire}

Survey questionnaires created from reviewing components of proposed CCSC were distributed and collected from 350 participants referred to CCSC in Thailand. The sample focused on farmers, banks and service providers as stakeholders in the supply chain. Questionnaire in Thai language is consisted of 3 parts:

- Demographic data of the respondent

- Five points Likert-scale rating of 6 components that are perceived to be usable for assessing the hypotheses

The sample focused on cassava chip farmers and agricultural services. The data collection occurred during October 2018 to February 2019 using a questionnaire with a five-point Likert scale. The questionnaire was sent directly to participants who responded through a survey by e-mail and was sent to participants that had not answered the survey

- Open-ended remarks and suggestions

Responses from Part 3 are used to develop CSCS mobile application of the study. The questionnaire was sent directly to participants who responded through a survey by e-mail and was sent to participants that had not answered the survey. the result analyzes relation through the linear regression analysis using SPSS.

\subsection{CCSC mobile application development}

Develop an CCSC in Thailand using Android version 5.2, Visual Studio 2015, WordPress 4.9.x on SQL Server 2012, jQuery, HTML, Java script and Chart were to be a CCSC mobile application installed.

\section{$4 \quad$ Result}

Budiman, R. (2013). Utilizing Skype for providing learning support for Indonesian distance Survey questionnaires created from reviewing components of proposed CCSC framework were distributed and data collected from 298 participants referred to CCSC in Thailand. The response rate was 298 participants from 350 (85\%) participants.

The result will be depended on methodology by using Linear Regression Analysis. This research used linear regression models to test the components of CSC framework. This analysis validated our instrument and the multi-item scales, as shown in the Appendix. Testing hypothesis will be demonstrated further validation.

\subsection{General information}

The total respondents were 298 persons; 177 (59.4\%) were male and 121 (40.6\%) were female. the highest of respondents aged between $36-45$ years old were 158 per- 
sons $(53 \%)$ followed by age of 26-35 years old were 79 persons $(26.5 \%)$, over 45 years were 50 persons $(16.8 \%)$ and aged under 26 years old equal 11 persons $(3.7 \%)$. Furthermore, most respondent had a master degree with 207 persons $(69.5 \%)$.

\subsection{Testing hypothesis}

From the research output of Linear Regression Analysis (see appendix), the components of CCSC will be demonstrated in the table 3.

Table 3. Descriptive Statistics

\begin{tabular}{|l|c|c|c|}
\hline \multicolumn{1}{|c|}{ Components } & Mean & Std. Deviation & N \\
\hline CSC & 4.51 & .501 & 298 \\
\hline Business Management & 4.53 & .501 & 298 \\
\hline Information Technology & 4.53 & .500 & 298 \\
\hline Value Added Process & 4.56 & .498 & 298 \\
\hline SC Relationship & 4.57 & .496 & 298 \\
\hline Environment Uncertainties & 4.33 & .476 & 298 \\
\hline Customer Satisfaction & 4.77 & .501 & 298 \\
\hline
\end{tabular}

The result from Linear Regression Analysis used SPSS to test hypotheses. It can be synthesized into three groups of result. The first group with the highest priority is Customer Satisfaction have the highest average equal to 4.77 with standard deviation 0.496 , a statistical significance of 0.00 is less than 0.05 . The second group with medium priority comprises SC Relationship, Value-Added Process and Information Technology equal to Business Management which has an average of 4.57 with standard deviation $0.498,4.56$ with standard deviation $0.498,4.53$, deviation of 0.500 and 501 , this group has statistical significance less than 0.05 respectively. The last group with minimum priority is Environment Uncertainties is lowest average equal to 4.33 with standard deviation 0.476 , a statistical significance of 0.03 is less than 0.05 . It was clear that all components ware supported the hypothesis.

\section{Discussion}

This research aimed to study a component of CSC which supported implement $\mathrm{CSC}$ in Thailand by investigating the relations between six components such as business management, information technology, value added process, SC relationship, environment uncertainties, customer satisfaction with CSC Model, a statistical significance need to less than 0.05 . The result clearly demonstrated that all components ware supported the hypothesis by statistical result that described below related output of Linear Regression Analysis.

This research also aims to develop the prototype of CCSC mobile application to create the collaboration in cassava chip industry. All components are also needed to support cassava chip stakeholder such cassava chip farmer, agricultural co-operative, agricultural service provider, buyer. The mobile application should be developed to 
create the supply chain relationship with cassava chip stakeholders. The CCSC mobile application prototype was developed based on six components. Users in mobile application are divided into five main groups are 1) Cassava chip farmer, 2) Agricultural co-operative, 3) Agricultural service provider, 4) Buyer, and 5) Application administration. The cassava chip farmer interfaces show personal and geo-information (see Figure 2).

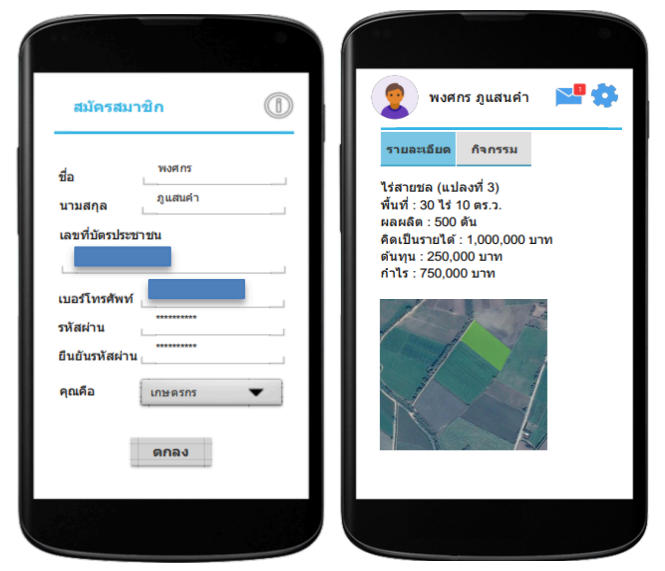

Fig. 2. CCSC mobile application prototype

The CCSC mobile application allows agricultural service providers to add their services with service cost to the system. It also allows agricultural co-operative and buyer to add their contact and information for farmer selling their cassava chip. All of activities can be chosen by cassava chip farmer in mobile application which is managed by administrator (see Figure 3 ).
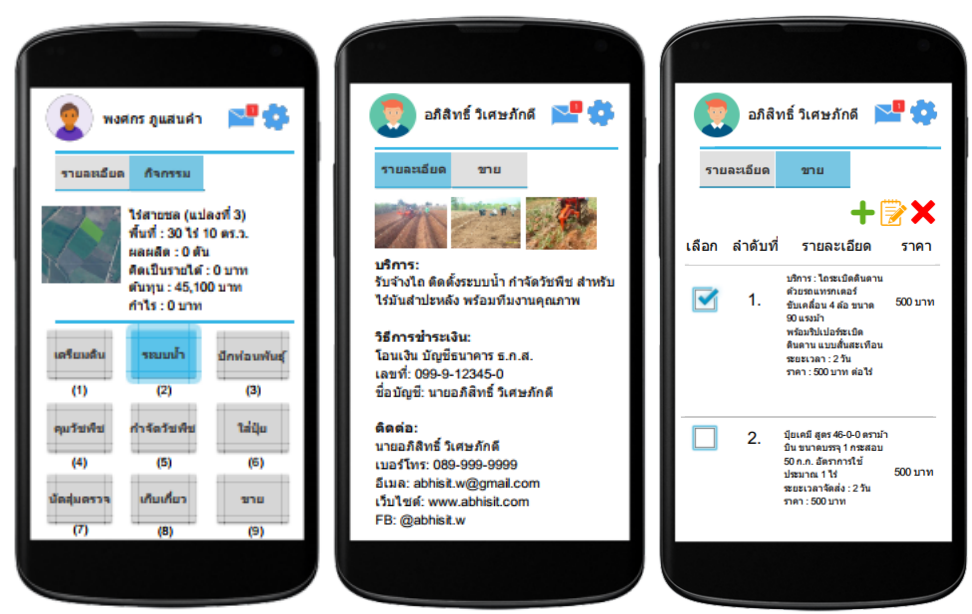

Fig. 3. Collaborative activities in CCSC mobile application 


\section{Conclusion}

The concept of CCSC is a collaboration of stakeholders in cassava chip to increase farmer income in Thailand. However, there is no research identifying components and develop to mobile application which becomes the key activity to transform the previous farmer work process to a farmer digitalized process this research proposed a new workable CCSC, developed from Linear Regression Analysis that derived six components.

This research can be concluded that the research contributes useful information to cassava chip supply chain especially cassava chip farmers in Thailand on what components can be used for influent CSC model in the supply chain. The result was clear that all components such as business management (H1), information technology $(\mathrm{H} 2)$, value added process (H3), SC relationship (H4), environment uncertainties (H5), customer satisfaction (H6) by statistical result in this research. However, due to its importance, researchers think that it should still be included as the part of CCSC. Finally, the prototype of CCSC mobile application was developed based on regression analysis. The mobile application can use for collaboration of cassava chip supply chain. The application will be a paradigm shift of cassava chip farmer in Thailand and the process result will be more accurate.

However, this research limit to cassava chip in Thailand and the result for all components was a comparatively rough scale for statistical analysis. Moreover, recommendation for practice and future research, for the practice should use technology acceptance model to measured users' attitudes of the model and the perceived usefulness of the model. For future researchers should expand and further study on scale for other agriculture in Thailand such as palm oil and rice

\section{$7 \quad$ References}

[1] Aker, J. C. \& Mbiti, I. (2010). Mobile phones and economic development in Africa. Journal of Economic Perspectives. 24, pp. 207-232. https://doi.org/10.1257/jep.24.3.207

[2] Azevedo, S. G., Silva, M. E., Matias, J. C. O. \& Dias, G. P. (2018). The Influence of Collaboration Initiatives on the Sustainability of the Cashew Supply Chain. Sustainability, 10(2075), pp. 1-29. https://doi.org/10.3390/su10062075

[3] Bowersox, D. J. (1990). The Strategic Benefits of Logistics Alliances. Harvard Business Review, 68(4), pp. 36-43.

[4] Cullen, A. J. \& Taylor, M. (2009). Critical success factors for B2B e-commerce use within the UK NHS pharmaceutical supply chain. International Journal of Operations \& Production Management, 29(11), pp. 1156-1185. https://doi.org/10.1108/01443570911000177

[5] Dinter, B. (2013). Success factors for information logistics strategy - an empirical investigation. Decision Support Systems, 54(3), pp. 1207-1218. https://doi.org/10.1016/j.dss.20 $\underline{12.09 .001}$

[6] Global Trade Atlas ${ }^{\circledR}$. (2018). Thailand Export Statistics to China. Retrieved from https://www.gtis.com/gta/secure/htshts_wta.cfm?commodity=071410andcomparison=YE ARLYandim-

pexp $=$ Eandstat $=$ Vandyear $=2017$ andmonth $=12$ andcountry $=$ Thailandandpartner $=$ Chinaan dorderby $=\mathrm{V} 5$ DESC 
[7] Gunasekaran, A., Lai, K. H., \& Edwin Cheng, T. C. (2008). Responsive supply chain: a competitive strategy in a networked economy. The International Journal of Management Science, 36(4), pp. 549-564. https://doi.org/10.1016/j.omega.2006.12.002

[8] Grunert, K. G. (2005). Food quality and safety: consumer perception and demand. European Review of Agricultural Economics. 32(3), pp. 369-391. https://doi.org/10.1093/eur $\underline{\mathrm{rag} / \mathrm{jbi011}}$

[9] Handayati, Y., Simatupang, T. M., \& Perdana, T. (2015). Agri-food Supply chain coordination: the state-of-the-art and recent developments. Logistics Research, 8(5). https://doi. org/10.1007/s12159-015-0125-4

[10] Halewood, N. J. \& Surya, P. (2012). Mobilizing the Agricultural Value Chain. http://sitesources.worldbank.org/EXTINFORMATIONANDCOMMUNICATIONANDTE CHNOLOGIES/Resources/IC4D-2012-Chapt

[11] Hong, J. Y., Suh, E. H. \& Hou, L. Y. (2008). Identifying the factors influencing the performance of reverse supply chains (RSC). International Journal of Sustainable Engineering, 1(3), pp. 173-87. https://doi.org/10.1080/19397030802511004

[12] Hu, A. H. \& Hsu, C. W. (2010). Critical factors for implementing green supply chain management practice: an empirical study of electrical and electronics industries in Taiwan. Management Research Review, 33(6), pp. 586-608. https://doi.org/10.1108/01409171011 $\underline{050208}$

[13] Hwang, B. N. \& Lu, T. P. (2013). Key success factor analysis for e-SCM project implementation and a case study in semiconductor manufacturers. International Journal of Physical Distribution \& Logistics Management, 43(8), pp. 657-683. https://doi.org/10.11 08/ijpdlm-03-2012-0062

[14] Kalogiannakis, M., \& Papadakis, St. (2018). An Evaluation of Greek Educational Android Apps for Pre-Schoolers. In Finlayson, O., McLoughlin, E., Erduran, S., \& Childs, P. (Eds.), Electronic Proceedings of the ESERA 2017 Conference. Research, Practice and Collaboration in Science Education, Part 4/Strand 4 (co-ed. Kalle Juuti \& Eleni A. Kyza, Digital Resources for Science Teaching and Learning), (pp. 593-603). Dublin, Ireland: Dublin City University. ISBN 978-1-873769-84-3. https://doi.org/10.1007/978-3-030$\underline{17219-0}$

[15] Kim, J. \& Rhee, J. (2012). An empirical study on the impact of critical success factors on the balanced scorecard performance in Korean green supply chain management enterprises. International Journal of Production Research, 50(9), pp. 2465-83. https://doi.org/10.10 $\underline{80 / 00207543.2011 .581009}$

[16] Kuei, C. H., Madu, C. N. \& Lin, C. (2008). Implementing supply chain quality management. Total Quality Management, 19(11), pp. 1127-1141. https://doi.org/10.1080/1478336 $\underline{0802323511}$

[17] Kumar, S., Luthra, S., \& Haleem, A. (2014). Critical success factors of customer involvement in greening the supply chain: an empirical study. International Journal of Logistics System and Management, 19(3), pp. 283-310. https://doi.org/10.1504/ijlsm.2014.065498

[18] Lambert, D. M., Knemeyer A. M. \& Gardner J. T. (2004). Supply Chain Partnerships: Model Validations and Implementation. Journal of Business Logistics, 25(2), pp. 21-42. https://doi.org/10.1002/j.2158-1592.2004.tb00180.x

[19] Lao, S. I., Choy, K. L., Ho, G. T. S., Tsim, Y. C. \& Chung, N. S. H. (2011). Determination of the success factors in supply chain networks: a Hong Kong-based manufacturer's perspective. Measuring Business Excellence, 15(1), pp. 34-48. https://doi.org/10.1108/13683 $\underline{041111113231}$

[20] Lönngren, H. M., Rosenkranz, C. \& Kolbe, H. (2010). Aggregated construction supply chains: success factors in implementation of strategic partnerships. Supply Chain Man- 
agement: An International Journal, 15(5), pp. 404-411. https://doi.org/10.1108/135985410 $\underline{11068297}$

[21] Luthra, S., Garg, D., \& Haleem, A. (2014). Critical success factors of green supply chain management for achieving sustainability in Indian automobile industry. Production Planning \& Control.

[22] Ministry of Africulture and Cooperatives. (2017). The Twenty-year Agriculture and Cooperatives Strategy (2017-2036). Bangkok, Thailand.

[23] Mothilal, S. \& Nachiappan, S. (2011). Linking success factors to financial performance. American Journal of Applied Sciences, 8(3), pp. 284-289. https://doi.org/10.3844/ajassp.20 11.284 .289

[24] Mothilal, S., Gunasekaran, A., Nachiappan, S. P. \& Jayaram, J. (2012). Key success factors and their performance implications in the Indian third-party logistics (3PL) industry. International Journal of Production Research, 50(9), pp. 2407-2422. https://doi.org/10.10 $\underline{80 / 00207543.2011 .581004}$

[25] Narus, J. A. \& James C. A. (1996). Rethinking Distribution: Adaptive Channels. Harvard Business Review, 74(4), pp. 112-120.

[26] Nyaga, G., Whipple, J. \& Lynch, D. (2010). Examining supply chain relationships: do buyer and supplier perspectives on collaborative relationships differ? Journal of Operations Management, 28(2), pp. 101-114. https://doi.org/10.1016/j.jom.2009.07.005

[27] Office of Agricultural Economics Thailand. (2017). Thailand agricultural statistics 2017.

[28] Papadakis S., Kalogiannakis M. \& Zaranis N. (2018). Educational apps from the Android Google Play for Greek preschoolers: A systematic review. Computers \& Education, 116, pp. 139-160. https://doi.org/10.1016/j.compedu.2017.09.007

[29] Piyachomkwan, K. \& Tanticharoen, M. (2011). Cassava Industry in Thailand: Prospects. The Journal of the Royal Institute of Thailand, 3, pp. 160-170.

[30] Rajesh, R., Pugazhendhi, S., Ganesh, K., Yves, D., Lenny Koh, S. C. \& Muralidharan, C. (2011). Perceptions of service providers and customers of key success factors of thirdparty logistics relationships-an empirical study. International Journal of Logistics Research and Applications, 14(4), pp. 221-250. https://doi.org/10.1080/13675567.2011.635 $\underline{640}$

[31] Samaddar, S., Nargundkar, S., \& Daley, M. (2006). Inter-organizational information sharing: The role of supply network configuration and partner goal congruence. European Journal of Operational Research, 174(2), pp. 744-765. https://doi.org/10.1016/j.ejor.2005. $\underline{01.059}$

[32] Singh, S. \& Al-Hakim, L. (2009). Managing supply chain at high technology companies. In: The 4th International Conference of on Cooperation and Promotion of Information Resources in Science and Technology (COINFO), Beijing, China, pp. 400-409. https://doi. org/10.1109/coinfo.2009.83

[33] Siriroth, K. (2008). Lessons learned from the development of processing systems and markets for Thai cassava, In: Consultation on Cassava Processing, Utilization and Marketing, Natural Resources Institute, University of Greenwich, Medway, UK.

[34] Siriyod, T., Jongsureyapart, C., Nimsai, S. \& Chiamsiri, S. (2018). Risk Modelling of Thai Cassava Chip Supply Chain as Export to China. In: The 7th Business, Economics and Communications International Conference.

[35] Thoo, A. C., Huam, H. T., Rosman, M. Y., Rasli, A. M. \& Hamid, A. B. A. (2011). Supply chain management: success factors from the Malaysian manufacturer's perspective. African Journal of Business Management, 5(17), pp. 7240-7247. 
[36] Vereecke A. \& Muylle S. (2006). Performance improvement through supply chain collaboration in Europe. International Journal of Operations \& Production Management, 26 (11), pp. 1176-1198. https://doi.org/10.1108/01443570610705818

[37] Wittstruck, D., \& Teuteberg, F. (2012). Understanding the success factors of sustainable supply chain management: empirical evidence from the electrics and electronics industry. Corporate Social Responsibility and Environmental Management, 19(3), pp. 141-158. https://doi.org/10.1002/csr.261

[38] Wu, M. Y. \& Weng, Y. C. (2010). A study of supplier selection factors for high-tech industries in the supply chain. Total Quality Management, 21(4), pp. 391-413. https://doi. org/10.1080/14783361003606662

\section{Authors}

Thanika Chintanapunt is Founder and Developer the $1^{\text {st }}$ Ethanol Plant in Thailand. (Thai Agro Energy PLC.(TAE)), Thailand. She often works as Creator, developer, investor and Director of Impress Ethanol 200,000 LPD and in the process of expanding production capacity to 500,000 LPD from zero and is Founder and Director of Thai Ethanol Manufacturing Association. She is now $\mathrm{PhD}$ candidate in Technopreneurship and Innovation Management Program, Graduate School, Chulalongkorn University, Thailand.

Assistant Prof. Rath Pichyangkura, Ph.D., graduated Ph.D. in Biochemistry, Department of Biochemistry, Michigan State University, East Lansing, Michigan, USA. He is now Vice Head Department for Research Affairs Faculty member Department of Biochemistry, Faculty of Science, Chulalongkorn University, Payathai Road, Bangkok 10330). He works also as a Committee member for National Innovation Agency (NIA) “Open Innovations program", (Thailand). He is the Editor-inChief of the journals iJOE, iJET, and iJIM at online-journals.org.

Article submitted 2019-07-03. Resubmitted 2019-08-30. Final acceptance 2019-09-03. Final version published as submitted by the authors. 


\section{$9 \quad$ Appendix}

Table 4. Linear Regression Analysis Result

\begin{tabular}{|c|c|c|c|c|c|c|}
\hline \multirow[t]{2}{*}{ Model } & & $\begin{array}{l}\text { Unstandard- } \\
\text { ized Coeffi- } \\
\text { cients }\end{array}$ & $\begin{array}{l}\text { Standardized } \\
\text { Coefficients }\end{array}$ & \multirow[t]{2}{*}{ Beta } & \multirow[t]{2}{*}{$\mathbf{t}$} & \multirow[t]{2}{*}{ Sig. } \\
\hline & & $B$ & Std. Error & & & \\
\hline \multirow[t]{8}{*}{1} & (Constant) & -.185 & .369 & & .500 & 617 \\
\hline & $\mathrm{CSC}$ & .520 & .037 & .520 & 14.03 & .000 \\
\hline & Business Management & .098 & .037 & .097 & 2.671 & .002 \\
\hline & Information Technology & .643 & .219 & .638 & 2.931 & .004 \\
\hline & Value Added Process & -.126 & .037 & -.125 & -3.406 & .001 \\
\hline & SC Relationship & .582 & .044 & .545 & 13.292 & .000 \\
\hline & Environment Uncertainties & -.133 & .044 & -.113 & -3.016 & .003 \\
\hline & Customer Satisfaction & -.229 & .053 & -.229 & -4.278 & .000 \\
\hline
\end{tabular}

Linear Regression Analysis

Model Summary ${ }^{\mathrm{b}}$

\begin{tabular}{|c|c|c|c|c|}
\hline Model & $\mathbf{R}$ & R Square & Adjusted Square & $\begin{array}{c}\text { Std. Error of the } \\
\text { Estimate }\end{array}$ \\
\hline 1 & $.809^{\mathrm{a}}$ & .654 & .643 & .299 \\
\hline
\end{tabular}

a. Predictors: (Constant), Business, InfoTech, valueAdded, SCrelation, Environment, Customer b. Dependent Variable: CSC

\begin{tabular}{|l|l|c|c|c|c|c|}
\hline \multicolumn{2}{|c|}{ ANOVAa } \\
\hline \multicolumn{2}{|l|}{ Model } & $\begin{array}{c}\text { Sum of } \\
\text { Squares }\end{array}$ & df & Mean Square & F & Sig. \\
\hline & Regression & 48.717 & 9 & 5.413 & 60.495 & $.000 \mathrm{~b}$ \\
\hline & Residual & 25.770 & 288 & .089 & & \\
\hline & Total & 74.487 & 297 & & & \\
\hline
\end{tabular}

a. Dependent Variable: CSC

b. Predictors: (Constant), Business, InfoTech, valueAdded, SCrelation, environment, customer 